\title{
Increasing Accountability for Operational School (Bos) Cost Management Funds (Study at Sumenep High School 2, Bluto 1 High School and Sumenep Vocational School 1)
}

\author{
Sugiono Eksantoso \\ Student of Do ctor Study Program of Administration Science- FISIP. \\ University 17 Agustus 1945 Surabaya, Semolowaru Street No 45 \\ Surabaya city - Indonesia \\ V. Rudy Handoko \\ Endro Tjahyono
}

\begin{abstract}
The School Operational Assistance Program (BOS) is a government policyintended for the purpose of freeing the cost of education for studentsless able and lighten the burden on students in the future. This study aims to analyze the planning, use and supervision of School Operational Assistance (BOS) funds in SMAN 2 Sumenep, SMAN 1 Bluto and SMKN 1 Sumenep. In this study a qualitative approach was used. The object of this research was carried out in three objects that have different characteristics, namely SMAN 2 Sumenep, SMAN 1 Bluto and SMKN 1. Methods of data collection techniques used three data collection techniques, namely: (1) in-depth interviews (in-depth interview), (2) observation, and (3) documentation study. In this study data analysis was performed as recommended by Miles and Huberman (1992), and Mantja (1997), namely: (1) data reduction, (2) data presentation, and (3) conclusions. The results showed (1) In the administration of financial components and operational financing in schools, SMAN 2 Sumenep, SMAN 1 Bluto and SMKN 1 Sumenep have been implemented well starting from the planning, implementation, accountability and reporting stages. (2) Accountability and transparency in the management of BOS funds have also been running well (3) There is a mutual relationship between transparency and accountability in managing BOS funds. Transparency can encourage increased accountability in the management of BOS funds. While accountability will be difficult to implement without transparency in the process of managing BOS funds.
\end{abstract}

Keywords: BOS, BOS Management, Accountability

DOI: $10.7176 / \mathrm{PPAR} / 10-1-06$

Publication date: January $31^{\text {st }} 2020$

\section{INTRODUCTION}

As mandated in the 1945 Constitution of the Republic of Indonesia, article 31 paragraph (1): Every citizen has the right to receive teaching and paragraph (2): The government is obliged to guarantee the rights of citizens to obtain educational services by organizing a national teaching system.

In this regard, the government took a number of policies including (1) to sharpen the use of the education function budget to be more optimal, (2) Optimizing the use of the budget by 7.3 percent from a total of 20 percent of the education function budget. The manifestation of this government policy was the creation of a School Operational Fund (BOS) assistance program. The BOS program is intended to prevent children dropping out of school because of limited funds. The BOS program is planned on an ongoing basis in accordance with needs analysis in schools.

In order to achieve the distribution of BOS funds on target, schools must prepare long-term work plans, annual work plans based on school self-evaluation and school budget activity plans (RKAS) prepared with school residents to accommodate the needs of infrastructure facilities and non-physical needs that support school operations in a manner overall (Duta and Riharjo, 2013).

The current problems are related to the misappropriation of BOS funds and ineffectiveness in managing BOS funds, starting from allocating funds that are not based on school needs but on budget availability, financial misuse to enrich themselves, manipulating financial reporting, financial expenditure that is not appropriate. This is due to the lack of attention and involvement of all education stakeholders.

The purpose of this study is to analyze the planning, use and supervision of School Operational Assistance (BOS) funds at SMAN 2 Sumenep, SMAN 1 Bluto and SMKN 1 Sumenep.

\section{RESEARCH PROCEDURES}

This research uses a qualitative approach. This research is not to test hypotheses, but rather to describe data and process it descriptively about the focus of research or to find patterns that might be developed into theory 
(Nasution, 1996).

The object of this study was conducted in three objects that have different characteristics, namely SMAN 2 Sumenep, SMAN 1 Bluto and SMKN 1 Sumenep. Researchers as key instruments, informants in this study include the Principal, Treasurer and Committee of Sumenep 2 Public High Schools, Bluto 1 High School and Sumenep 1 Vocational School.

Methods of data collection techniques used three data collection techniques, namely: (1) in-depth interviews (indepth interview), (2) observation, and (3) documentation studies. In this study data analysis was performed as recommended by Miles and Huberman (1992), and Mantja (1997), namely: (1) data reduction, (2) data presentation, and (3) conclusions. This research was also carried out checking the validity of the data using triangulation techniques which included triangulation of data collection, triangulation of data sources, checking of members (member check), and peer discussion (peer-de briefing).

\section{THEORY BASIS}

1. Education Funding Policy

Education Funding Policy is one of the decisions of public authorities in the context of the mandate of the Act. Education funding or funding has been regulated in the 1945 Constitution of the Republic of Indonesia Article 31 Paragraph 3 of IV amendments. The education funding policy can be referred to as part of State policy, namely as a product of the state whose policy is influenced and motivated by a political interest (Carnoy, 1982) or which we often refer to as Autonomy.

Autonomy according to Yoyon Bahtiar Irianto (2012: 73-74) is defined as self-government regulation (zelfwentgeving) or more accurately referred to as granting the right or power of self-government regulation to autonomous bodies. There is also a form of education autonomy in schools in the form of expanding school authority in managing funding and learning systems (Syakdiah, 2005). Along with the implementation of regional autonomy, the central government also began implementing a decentralized policy in education management.

Decentralization of education management implies that the delegation of authority from the government to the regions to make management decisions and develop their own plans in overcoming the problem of education, with reference to the national education system (Yoyon Bahtiar Irianto, 2012: 91).

The substance of decentralization in the management of education, includes aspects: (1) Educational legislation, (2) Organizational structure and educational institutions; (3) Development of educational curricula; (4) Professionalisation of education personnel; (5) Educational facilities and infrastructure; (6) Education Funding.

2. Accountability

Accountability is a term that embodies the level of responsibility of a particular person or institution relating to the administration system. Ngguna, et al. (2017) states that accountability is with regard to accountability for providing information on all activities and performance of the trustee to the trustee. The principle of accountability can be applied in implementing the BOS budget accountability system in a school institution. The following is an illustration of the application of the principle of accountability in the implementation of the BOS budget accountability system in schools, which involves two dimensions, internal accountability and external accountability. Internal accountability concerns the relationship between the school manager and the community, the school, parents of students between the school and the institutions above it (the education office). Whereas external accountability concerns the relationship between fellow citizens between the principal and the school committee, and between the principal and the teacher council. School managers must be able to account for all components of SBM management to the community. The first component that must carry out accountability is the teacher. Why, because the core of the whole implementation of school management is the teaching and learning process. And the first party where the teacher must be responsible for students. Teachers must be able to do this (Duta and Riharjo, 2013).

School Financial Management Principles Law No. 20/2003 article 48 states that the management of education funds is based on the principles of justice, efficiency, transparency, and public accountability.

3. School Financial Management

According to Rohiat (2008) financial management includes planning, use, data recording, reporting and accountability for the use of funds as planned. The purpose of financial management is to realize orderly financial administration so that the use of finance can be accounted for in accordance with applicable regulations.

In the implementation of financial management must pay attention to school development programs, school financial planning that refers to the implementation of education in schools as a whole. At the planning stage it also requires an analysis of the needs of school development within a certain period of time which is the main focus and needs attention. Needs in one fiscal year, five years, ten years, even twenty-five years 


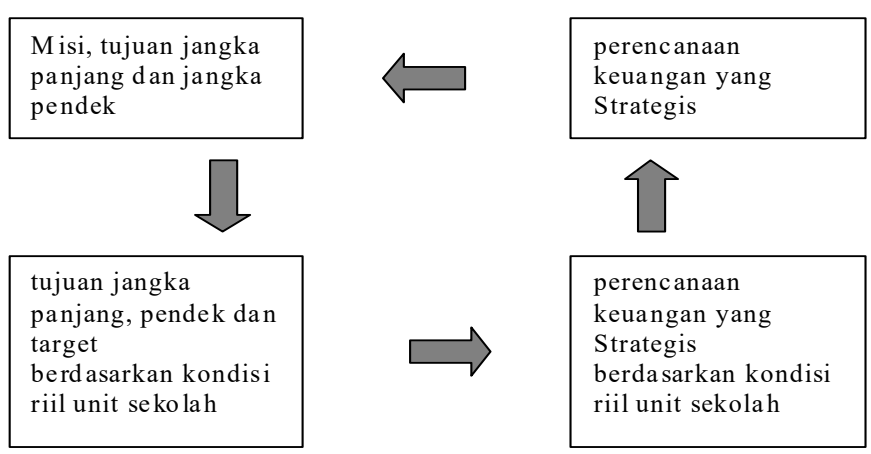

Figure 1.3 Strategic Financial Planning (Management)

\section{RESULTS AND DISCUSSION}

4.1. Conformity with BOS Management in Managing School Operational Assistance Funds (BOS) at SMAN 2 Sumenep, SMAN 1 Bluto and SMKN 1 Sumenep with.

Financial management can be interpreted as an act of financial administration / administration which includes recording, planning, implementation, accountability and reporting (Ministry of National Education, Directorate General of Primary and Secondary Education, 2000). Based on the analysis of documents obtained information that the Sumenep 2 Public High School, Bluto 1 Public High School and Sumenep 1 Public Vocational School in the administration of the financial component and operational financing at the school have been well implemented starting from the planning, implementation, accountability and reporting stages. Realization and BOS are also in accordance with the planning made and the budget quota

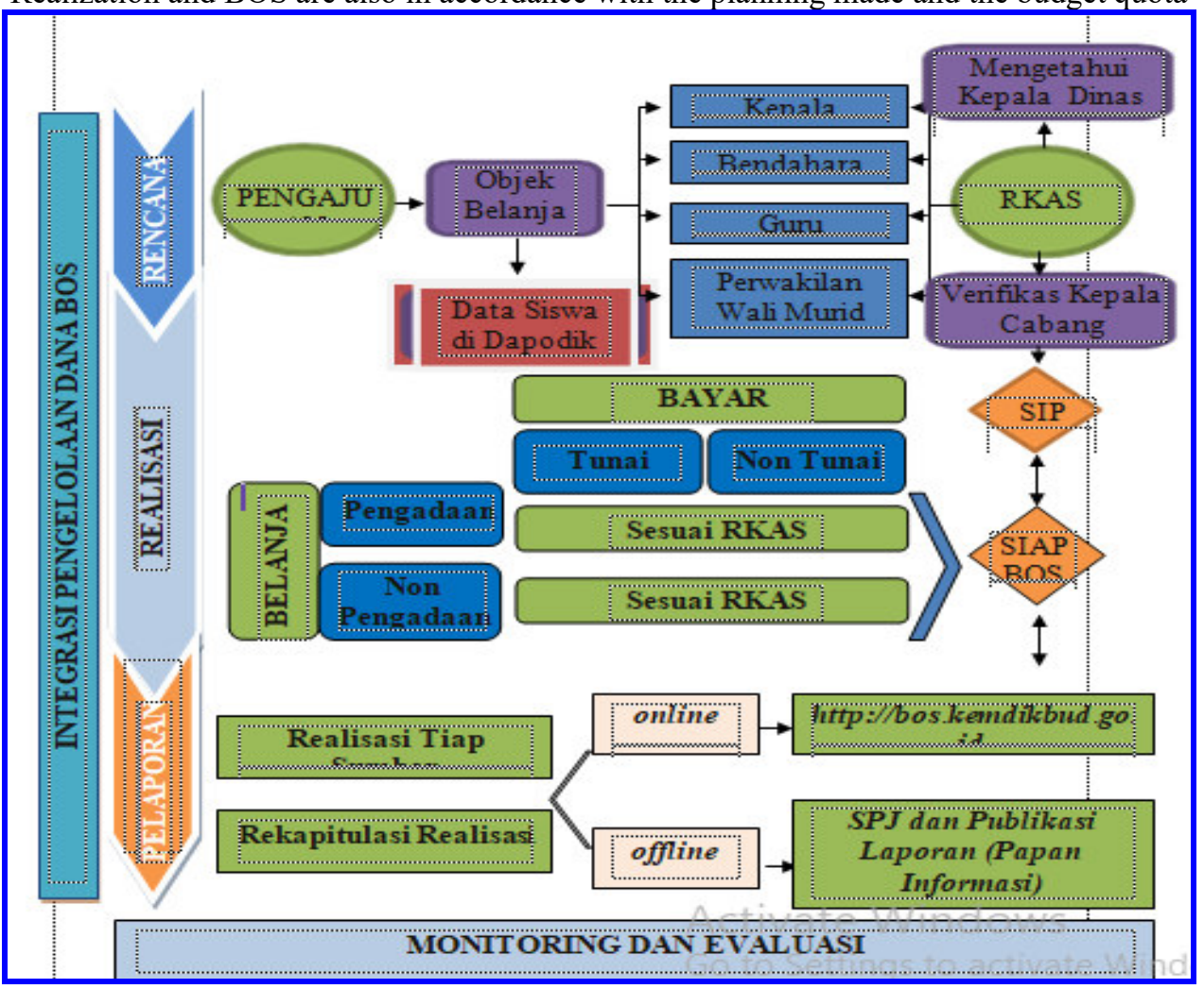

Gambar 1.2ManajemenPengelolaan Dana BOS

Figure 1.2 Management of BOS Fund Management

In the implementation also each school has been guided by the BOS financial managementguidelines or can be interpreted differently as "SAKERAH" management. "SAKERAH" management is the management of School Operational Assistance management that is still guided by the BOS SOP. 


\begin{tabular}{|c|c|c|c|c|c|c|}
\hline \multicolumn{7}{|c|}{ Prosedur Pelayanan Laporan BOS } \\
\hline \multirow[b]{2}{*}{ NO } & \multirow[b]{2}{*}{ KEGIATAN } & \multirow{2}{*}{$\begin{array}{c}\text { Pelaksana } \\
\text { Pemohon Analisi Verifikasi Tim BOS dan } \\
\text { Persetujuan Kepala Cabang }\end{array}$} & \multicolumn{3}{|c|}{ Mutu Baku } & \multirow[b]{2}{*}{ Keteranagr } \\
\hline & & & Kelengkapan & Waktu & Out Put & \\
\hline 1 & $\begin{array}{l}\text { Verifikasi RKASBOS sesuai peruntukan } \\
\text { 4 Belaria. Untuk sw asta NPHD }\end{array}$ & & $\begin{array}{l}\text { Dokumen Asli dan Foto copy Dokumen } \\
\text { diserahkan ke CabangDinas Pendidikan } \\
\text { Willayah Sumenep untuk sekolah Negeri }\end{array}$ & 24 menit & \begin{tabular}{|l} 
Berkas persyaratanl \\
kelengkapan
\end{tabular} & - \\
\hline 2 & $\begin{array}{l}\text { Apload RKSA ke Dalam Aplikasi SIP BOS } \\
\text { ditandatangani Kepala Cabang }\end{array}$ & & $\begin{array}{l}\text { Dokumen yang sudah disetujuiKepala } \\
\text { Cabang }\end{array}$ & 60 menit & \begin{tabular}{|l} 
Berkas persyaratanl \\
kelengkapanyang \\
memenuhi isyarat
\end{tabular} & - \\
\hline 3 & $\begin{array}{l}\text { Verifikasikeabsahan Laporan pe } \\
\text { triwulan }\end{array}$ & & $\begin{array}{l}\text { Dokumen } 10 \text { Peruntukan untuk SMA, PK- } \\
\text { PLK dan } 12 \text { Peruntukan untuk SMK di } \\
\text { implementasikan ke } 8 \text { standart dan } 4 \text { beban } \\
\text { belaria }\end{array}$ & 60 menit & $\begin{array}{l}\text { Berkas persyaratanl } \\
\text { kelengkapanyang } \\
\text { memenuhi syarat }\end{array}$ & - \\
\hline 4 & Pencatatan atauPerekapan Laporan & & Dokumen laporan singkat K2 - 09 & 60 menit & \begin{tabular}{|l} 
Berkas persyaratanl \\
kelengkapanyang \\
memenuhisyarat
\end{tabular} & - \\
\hline 5 & $\begin{array}{l}\text { Penyetoran hasil Rekapitulasike Dinas } \\
\text { Pendidikan Provinsi Jawa Timur }\end{array}$ & & $\begin{array}{l}\text { Ke Sub Bidang SMA Bidang SMKK dan PK- } \\
\text { PLK }\end{array}$ & 720 menit & $\begin{array}{l}\text { Dokumen Rekab } \\
\text { laporan }\end{array}$ & - \\
\hline 6 & Verifikasi laporan SPJ Lengkap & & $\begin{array}{l}\text { Cabang Dinas Pendidikan Willayah } \\
\text { Sumenee, Disdik Prov Jatim, BPK, BPKAD, } \\
\text { Inspektorat Provinsi Jawa Timur. }\end{array}$ & 120 menit & \begin{tabular}{|l} 
Dokumen \\
Kepegaw aian yang \\
telah dilegalisit
\end{tabular} & - \\
\hline 7 & Proses Selesai & & $\begin{array}{l}\text { SPJ setelah dilakukan Verifikasi disimpan } \\
\text { di sekolah masing-masing }\end{array}$ & $\cdot$ & Proses Selesai & - \\
\hline
\end{tabular}

Figure 1.3 BOS SOP

"SAKERAH" management can be used as a reference by schools in implementing BOS governance. "SAKERAH" Management has the following meanings: (Sa): Pair Planning with Existing Technical Guidelines, (Ker): Work in Accordance with the RKAS and Available Budget Quota, (Ah): End with a Report in accordance with the Schedule.

4.2. Accountability in the Management of School Operational Assistance Funds (BOS) at SMAN 2 Sumenep, SMAN 1 Bluto and SMKN 1 Sumenep.

Accountability has an important role in managing BOS funds. Accountability in this study presented that in the management of School Operational Assistance (BOS) at SMAN 2 Sumenep is carried out in accordance with the 2018 BOS Management Technical Guidelines namely Permendikbud Number 1 of 2018 concerning Technical Guidelines for School Operational Assistance, so that actions and expenditures can be accounted to the public accountably.

Based on the analysis of documents and the results of interviews with the Principal, Treasurer and School Committee at Sumenep 2 Public High School, Bluto 1 Senior High School and Sumenep 1 Vocational School can be obtainedinformation that schools have made and reported accountability for BOS funds periodically and in a timely manner to the Education Office through the BOS Management Team. This is appropriatewith the principle of accountability put forward by Ngguna, et al. (2017) which says that accountability is related to accountability for providing information on all activities and performance of the trustee to the trustee. According to Wicaksono (2015) accountability is providing answers to parties with an interest in public sector organizations. The presentation of the BOS Funds Accountability Report at Sumenep 2 Public High Schools, Bluto 1 Public High Schools and Sumenep 1 Public Vocational Schools was made and presented in the form of BOS-K1, BOSK2, BOSK3, BOS-K4, BOS-K5, BOS-K6 Forms, which were reported to the Education Office. For the accountability report to the BOS Management Team in East Java Province, it is presented in the form of BOS$\mathrm{K} 7$ and BOS-K8 Forms, whereas for the accountability report to the public, it is done by sticking the BOS-K1 Form on the school notice board.

Based on the results of the analysis above, it appears that the management of BOS funds at SMAN 2 Sumenep, SMAN 1 Bluto and SMKN 1 Sumenep have been presented accountably in accordance with those stipulated under Permendikbud Number 1 of 2018 concerning Technical Guidelines for School Operational Assistance.

\subsection{Transparency in the Management of School Operational Assistance (BOS) at SMAN 2 Sumenep, SMAN 1} Bluto and SMKN 1 Sumenep

Transparency is a principle that guarantees access or freedom for everyone to obtain information about government administration. In this research the information is the management of School Operational Assistance (BOS). Transparency can create mutual trust between government, the community, and school members through the provision of information and ensuring ease in obtaining accurate and adequate information.SMAN 2 Sumenep, SMAN 1 Bluto and SMKN 1 Sumenep are very open insideprovide financial information both to the government and to the community, so that they can easily access and directly control the management of BOS 
funds in schools. This can be proven by allowing researchers to conduct research on school BOS financial management.

The application of transparency principles in the management of BOS funds at SMAN 2 Sumenep, SMAN 1 Bluto and SMKN 1 Sumenep can be seen from the planning of the use of BOS funds namely in the Preparation of School Activities and Budget Plans (RKAS) which have been carried out openly by involving the School Committee, Teachers and Educational Personnel.

Based on the previous discussion that Sumenep SMAN 2, Bluto 1 SMAN and Sumenep 1 SMKN have reported the amount of BOS funds received and reported the use of BOS funds both to the government and to the public. The form of transparency in the management of BOS funds at SMAN 2 Sumenep, SMAN 1 Bluto and SMKN 1 Sumenep is to provide an Accountability Report on the management of BOS funds to the government and to the public by reporting the receipt of funds using BOS funds through the school announcement board. In addition, the public transparency forms of SMAN 2 Sumenep, SMAN 1 Bluto and SMKN 1 Sumenep have reported the use of BOS funds through www.bos.kemendikbud.go.id

\subsection{Accountability and Transparency Analysis in the Management of School Operational Assistance (BOS) at} SMAN 2 Sumenep, SMAN 1 Bluto and SMKN 1 Sumenep

Based on the accountability and transparency analysis above it can be concluded that SMAN 2 Sumenep, SMAN 1 Bluto and SMKN 1 Sumenep have applied the principles of accountability and transparency well. This is evidenced by the Accountability Report on the Acceptance of Funds Using the BOS Funds and the openness regarding fund management

BOS in Fiscal Year 2017. This is in accordance with what has been regulated in Permendikbud Number 1 of 2018 concerning Technical Guidelines for School Operational Assistance on Technical Guidelines for Financial Use and Accountability of School Operational Assistance Funds Transparency can encourage increased accountability in the management of BOS funds. While accountability will be difficult to carry out without transparency and participation of all elements of the school in the process of managing BOS funds so that there is a mutual relationship between accountability and transparency

\section{CONCLUSION}

Based on the results of the research that has been done it can be concluded several things including:

1. In the administration of financial components and operational financing in schools, SMAN 2 Sumenep, SMAN 1 Bluto and SMKN 1 Sumenep have been implemented well starting from the planning, implementation, accountability and reporting stages. Realization and BOS are also in accordance with the plans made and the existing budget quota.

2. Accountability for managing BOS Funds at Sumenep 2 Public High School, Bluto 1 Senior High School and Sumenep 1 Public Vocational School have been running well, this can be seen in the form of accountability report on the use of BOS funds containing attachments to the BOS K1, BOS-K2, BOS-K3 forms, BOS-K4, BOS-K5, BOSK6, BOS-K7, BOS-K7a and BOS-K8 signed by the school principal and BOS Treasurer. The attached accountability form is sent to the Education and Culture Office through the BOS Management Team.

3. Transparency in the management of BOS Funds at SMAN 2 Sumenep, SMAN 1 Bluto and SMKN 1 Sumenep has been going well. This can be seen from the ease of access and openness in planning as well as being open about information on receiving funds, using funds and information provided on managing BOS funds in the form of RKAS. And the participation of school residents in managing the BOS funds budget.

4. Application of the principle of accountability and transparency In the management of School Operational Assistance (BOS) funds for 2017 SMAN 2 Sumenep, SMUT 1 Bluto and SMK 1 Sumenep SMAN 2 Finances have been running well in accordance with Ministry of Education and Culture Regulation No. 01 of 2018 regarding Technical Guidelines for the Use and Financial Responsibility of School Operational Assistance Funds for 2018 Budget Year.

5. There is a mutual relationship between transparency and accountability in managing BOS funds. Transparency can encourage increased accountability in the management of BOS funds. While accountability will be difficult to implement without transparency in the process of managing BOS funds.

\section{RECOMMENDATIONS}

1. The BOS Program is expected to be continued in order to realize the expectations of the community in getting a proper education.

2. For implementers both BOS officials and other related parties should further increase the socialization of the BOS Program not only within the school environment but outside the school so that parents are involved and know what the next management of the funds will be. Starting from the planning stage to reporting so that negative assumptions from the outside community can be minimized.

3. Evaluation and monitoring from the offices of both the District and Provincial Offices are also expected to 
continue to be made to know the extent of the success of BOS in schools, what obstacles are found by the BOS program, and how to make the BOS program run sustainably and develop, thus the objectives to be achieved will also be more leverage.

4. There is a need for training in the form of technical guidance for human resources, especially BOS managers, to be able to work collaboratively and be able to carry out their duties according to Technical Guidelines correctly so that their implementation can run effectively and efficiently. BOS fund managers also need to be improved through further education so that BOS fund managers truly understand the implementation instructions and technical instructions about BOS and are able to understand the job descriptions of BOS managers.

\section{REFERENCES}

Arikunto, Suharsimi, 2010. Research Procedure for a Practical Approach, Jakarta: Rineka Cipta Publisher National Education Department, 2003.

Law Number 20 of 2003, Regarding the National Education System, Jakarta: Ministry of National Education

Dwiyanto, Agus, 2014. Realizing Good Governance through Public Services. Yogyakarta: Gajah Mada University Publisher

Minarti Sri, 2011. School Management (Managing Educational Institutions Independently), Yogyakarta: ArRuzz Media Nasution, 2008. Legal Research Methods, page 174. Mandar Maju, Bandung

Permanent Ivan 2012. The Effect of Application of Government Accounting Standards on the Quality of Regional Government Financial Statements and Their Implications on Accountability in Bandung City Government. Essay. Bandung. Indonesian Computer University. Government Regulation, 2008.

Regulation of the Minister of Education and Culture of the Republic of Indonesia Number 51 of 2011 concerning Technical Guidelines for the Use of School Operational Assistance and Financial Reports for School Operational Assistance for Fiscal Year 2012.

Regulation of the Minister of Education and Culture of the Republic of Indonesia Number 1 of 2018 concerning Technical Guidelines for School Operational Assistance.

Minister of National Education Regulation No. 15 of 2010 concerning Minimum Service Standards for Basic Education.

Government Regulation No. 48 on Education Funding.

Government Regulation Number 17 of 2010 (amended by PP N0.66 / 2010) concerning Management and Implementation of Education.

Government Regulation Number 19 Year 2005 concerning National Education Standards.

Government Regulation Number 48 of 2008 concerning Education Funding. and Nepotism. Jakarta

Law Number 20 Year 2003 concerning the National Education System.

Law Number 32 of 2004 concerning Regional Government.

Law Number 32 of 2008 concerning Information Disclosure.

Widjanarko, M. and Sah understanding, P.A. 1996/1997. School Financial Management. Education Management Training Materials for Head of High Schools in Indonesia in Malang.

Winoto, S. 2007. The Role of School / Madrasah Committees in the Management Process of Improving Education Quality (Multi-Case Study in SMP Nusa Bangsa Malang and MTs Harapan Bangsa Malang). Dissertation. Malang State University.

Zamroni. 2000. Future Education Paradigm. Yogyakarta: Bigraf Publishing. 